\title{
Multiple Victims of Carbon Monoxide Poisoning in the Aftermath of a Wildfire: A Case Series
}

\section{Cenário Multivítimas de Intoxicação por Monóxido de Carbono num Incêndio Florestal: Série de Casos}

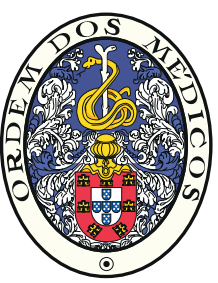

\author{
Luís Ramos dos SANTOS ${ }^{1}$, Magna ALVES-CORREIA¹, Margarida CÂMARA ${ }^{2,3}$, Manuela LÉLIS ${ }^{1}$, \\ Carmo CALDEIRA ${ }^{3,4,5}$, Maria da Luz BRAZÃO ${ }^{1}$, José Júlio NÓBREGA ${ }^{2,3}$ \\ Acta Med Port 2018 Mar;31(3):146-151 • https://doi.org/10.20344/amp.9811
}

\section{ABSTRACT}

Introduction: Carbon monoxide poisoning may occur in several contexts.

Material and Methods: Retrospective of 37 carbon monoxide poisoning cases that underwent hyperbaric oxygen during wildfires in Funchal in August 2016.

Results: The studied sample included 37 patients, mean age of 38 years, $78 \%$ males. Ten were firefighters, four children and two pregnant victims. Neurological symptoms were the most reported. Median carboxyhemoglobin level was 3.7\% (IQR 2.7). All received high-flow oxygen from admission to delivery of hyperbaric oxygen. Persistence of symptoms was the main indication for hyperbaric oxygen. Median time to hyperbaric oxygen was 4.8 hours (IQR 9.5), at 2.5 ATA for 90 minutes, without major complications. Discharge in less than 24 hours occurred in $92 \%$ of the cases. Thirty days follow-up: five patients presented clinical symptoms of late neurological syndrome; twelve patients were lost to follow-up. Carboxyhemoglobin levels on admission and mean time to hyperbaric oxygen were no different between those who did and did not develop the syndrome at 30 days ( $p=0.44$ and $p=0.58$, respectively).

Discussion: Late neurological syndrome at 30 days occurred in $20 \%$ and no new cases were reported at 12 months.

Conclusion: Use of hyperbaric oxygen appears to have reduced the incidence of the syndrome. This seems to be the first Portuguese series reporting use of hyperbaric oxygen in carbon monoxide poisoning due to wildfires. The authors intend to alert to the importance of referral of these patients because the indications and benefits of this treatment are well documented. This is especially important given the ever-growing issue of wildfires in Portugal.

Keywords: Brain Diseases; Carbon Monoxide Poisoning; Hyperbaric Oxygenation; Hypoxia, Brain; Portugal; Wildfires

\section{RESUMO}

Introdução: A intoxicação por monóxido de carbono pode ocorrer em diversos contextos.

Material e Métodos: Retrospectiva de 37 casos de intoxicação por monóxido de carbono submetidos a oxigenoterapia hiperbárica nos fogos do Funchal de agosto de 2016.

Resultados: Foram analisados 37 doentes, com média de 38 anos e $78 \%$ do sexo masculino; o universo de casos analisados incluiu 10 bombeiros, quatro crianças e duas grávidas; $80 \%$ reportaram sintomas neurológicos. O nível mediano de carboxihemoglobina foi de $3,7 \%$. Todos receberam oxigénio alto débito até iniciarem oxigenoterapia hiperbárica. A persistência de sintomas foi a principal indicação para oxigenoterapia hiperbárica. O tempo mediano para oxigenoterapia hiperbárica foi 4,8 horas, a 2,5 ATA durante 90 minutos, sem intercorrências relevantes. O tempo até alta foi inferior a 24 horas em $92 \%$ dos casos. Follow-up 30 dias: cinco doentes apresentavam sinais clínicos de síndrome neurológico tardio; doze foram perdidos no follow-up. Os níveis de carboxihemoglobina durante a admissão e tempo médio até oxigenoterapia hiperbárica não diferiram entre os doentes que desenvolveram a síndrome a 30 dias e os restantes ( $p=0,44$ e $p=0,58$, respetivamente).

Discussão: A ocorrência de síndrome neurológico tardio a 30 dias ocorreu em $20 \%$ dos doentes, não se tendo verificado novos casos ao fim de 12 meses.

Conclusão: A oxigenoterapia hiperbárica parece ter permitido reduzir a incidência de síndrome neurológico tardio. Esta é a primeira série de casos portuguesa que reporta exclusivamente a utilização de oxigenoterapia hiperbárica na intoxicação por monóxido de carbono por fogos florestais. Os autores pretendem alertar para importância destes doentes, cuja indicação terapêutica e benefício clínico deste tratamento está bem documentada, sobretudo atendendo à crescente problemática dos incêndios florestais em Portugal. Palavras-chave: Encefalopatias; Hipóxia Cerebral; Incêndios Florestais; Intoxicação por Monóxido de carbono; Oxigenação Hiperbárica; Portugal

\section{INTRODUCTION}

Carbon monoxide (CO) poisoning can occur in several contexts. It can be voluntary or accidental. The leading cause of CO poisoning is smoke inhalation, usually in enclosed spaces such as houses. United States (US) estimates of CO poisoning point to around 50000 cases annually, an incidence of 16 cases per $100000 .^{1}$ Additionally, the same author reported that almost $1500 \mathrm{CO}$ poisoned patients are treated with hyperbaric oxygen therapy (HBOT) in the US annually. ${ }^{2}$

A study from Braubach et al in Europe showed that from 1980 to 2008 there were 140490 deaths from CO poisoning, across 28 different countries, resulting in a mean

1. Internal Medicine Department. Hospital dos Marmeleiros, SESARAM. Funchal. Portugal.

2. Intensive Care Department. Hospital Central do Funchal, SESARAM. Funchal. Portugal.

3. Hyperbaric Medicine Unit. Hospital Central do Funchal, SESARAM. Funchal. Portugal.

4. General Surgery Department. Hospital Central do Funchal, SESARAM. Funchal. Portugal.

5. Emergency Department. Hospital Central do Funchal, SESARAM. Funchal. Portugal.

$\triangle$ Autor correspondente: Luís Ramos dos Santos. luisramossantos@sesaram.pt

Recebido: 05 de dezembro de 2017 - Aceite: 07 de março de 2018 | Copyright @ Ordem dos Médicos 2018 
mortality rate of 2.24 per 100000 inhabitants. ${ }^{3}$ Moreover, a study conducted in Portugal (2000 - 2007) showed 621 admissions due to $\mathrm{CO}$ poisoning. In such study, there was a national annual mean of 77.6 cases, roughly $2.2 \%$ of all admissions for intoxication and other drug effects. ${ }^{4}$

Inhaled $\mathrm{CO}$ can cause toxicity through several mechanisms by both hypoxic stress from binding to haemoglobin and intracellular sites, as well as non-hypoxic pathways such as oxidative stress, endothelial leukocyte adhesion, and lipid peroxidation. ${ }^{5}$

There is a large spectrum of clinical features due to CO poisoning ranging from nausea and dizziness to coma, with death occurring in about $1 \%-3 \%{ }^{6}$ Interestingly, initial carboxyhemoglobin $(\mathrm{COHb})$ level does not correlate with exhibited symptoms. ${ }^{6,7}$

CO poisoning is ideally diagnosed by a clinical triad: 1) symptoms consistent with $\mathrm{CO}$ poisoning, 2) history of recent $\mathrm{CO}$ exposure, and 3 ) elevated $\mathrm{COHb}$ levels. ${ }^{7,8}$ However, criteria are not rigid. ${ }^{5}$

$\mathrm{COHb}$ levels are considered to be elevated, and may produce symptoms, when $\geq 2 \%$ in non-smokers and more than $10 \%$ in smokers. ${ }^{5}$

Up to $40 \%$ of patients may remain with neuropsychiatric deficits, named the delayed neuropsychiatric syndrome (DNS)..$^{7}$ These include headache, cognitive impairment, lethargy, emotional liability, memory loss, dementia, psychosis, parkinsonism, chorea, apraxia, agnosia, peripheral neuropathy and urinary incontinence.5,9 Symptoms may resolve over time but there is high probability of becoming chronic. .,8,10,11 $^{-1}$

There is no known antidote for $\mathrm{CO}$ poisoning. However, administration of $100 \%$ normobaric oxygen therapy (NBOT) and HBOT may accelerate $\mathrm{CO}$ clearance. ${ }^{7}$ These are the current treatment options, with HBOT having conflicting results in the decrease of incidence of late neurologic sequelae. ${ }^{8}$ Some of the higher quality evidence comes from the study of Weaver et al, where HBOT showed significant improvement in long-term neurocognitive dysfunction. ${ }^{12}$

According to the Tenth European Consensus Conference on Hyperbaric Medicine from the European Committee for Hyperbaric Medicine, HBOT is recommended in the treatment of $\mathrm{CO}$ poisoning as a type 1 recommendation, level B evidence. Furthermore, it is stated that $100 \%$ oxygen should be applied immediately to any $\mathrm{CO}$ poisoned person as a first aid treatment (Type 1 recommendation, Level C evidence). Altered consciousness, clinical neurological, cardiac, respiratory or psychological signs regardless of the $\mathrm{COHb}$ level at the time of hospital admission and CO-poisoned pregnant women regardless of their clinical presentation and $\mathrm{COHb}$ level at hospital admission are both type 1 recommendation, level $B$ evidence. ${ }^{13}$ As such, persistence of symptoms despite NBOT is one of the main indications for the use of HBOT. ${ }^{13,14,15}$

Intense wild and urban fires swept the metropolitan area of Funchal in Madeira Island, Portugal, starting in August $8^{\text {th }}$ 2016 under the triad of extreme heat (mean temperatures of $29.5^{\circ}$ Celsius), low humidity and strong winds. This was an almost unprecedented set of environmental conditions for this subtropical Atlantic island that lasted five days. Wildfires progressed to urban areas leading to the evacuation of thousands of people, with hundreds coming to the emergency department (ED) for treatment. Moreover, three people were killed and over 300 buildings were damaged, leading the government to declare state of emergency for the city. We describe what we believe to be, in such a short period of time, the biggest Portuguese case series of patients undergoing HBOT for $\mathrm{CO}$ poisoning due to wildfires. The aims of this study were to describe a case series of $\mathrm{CO}$ poisoning in the context of wildfires and compare the DNS incidence at 30 days according to $\mathrm{COHb}$ concentration on arrival as well as the time to HBOT delivery.

\section{MATERIAL AND METHODS}

Retrospective, observational study of 37 patients that underwent hyperbaric oxygen due to $\mathrm{CO}$ accidental poisoning during the Madeira island wildfires in 2016 Hyperbaric oxygen session reports were reviewed from 8 through $11^{\text {th }}$ August, 2016, following intense wildfires that swept Funchal, Portugal. During this period an unprecedented case series underwent HBOT due to $\mathrm{CO}$ poisoning.

We collected demographic, clinical and laboratory data, as well as details from HBOT and early follow-up at 30 days and one year. A 30-day appointment was scheduled by Hyperbaric Medicine physicians from the institution that also co-author this study. Clinical interview and examination was conducted but no structured questionnaire was employed. A telephone contact for DNS symptom screening was performed at 12 months by the authors/investigators. Prior authorization was obtained from the institution's Ethics Committee, with favourable view. The decompression protocol was based on the tables and proceedings for dive with compressed air from the Defense and Civil Institute of Environmental Medicine - Canadian Military Forces. The paediatric group comprises the age group between $0-18$ years-old. Descriptive statistical analysis and comparison of medians with the Mann-Whitney test was performed using IBM SPSS Statistics for Windows v23 (Armonk, NY: IBM Corp.). Significance was set at a $p$ value $<0.05$.

\section{RESULTS}

A total of 37 patients aged between 14 - 71-yearsold underwent HBOT treatment. In this series, 10 were firefighters, four were children and two were pregnant victims. The demographic distribution can be analysed through Fig. 1.

Information regarding the site of exposure was present for 25 patients. The majority of these (96\%) experienced intoxication while outdoors. Two firefighters also reported exposure to indoor smoke. Descriptive data for the case series is presented in Table 1.

Most patients had neurological symptoms on admission $(n=30)$. Among these, headache was the commonest 


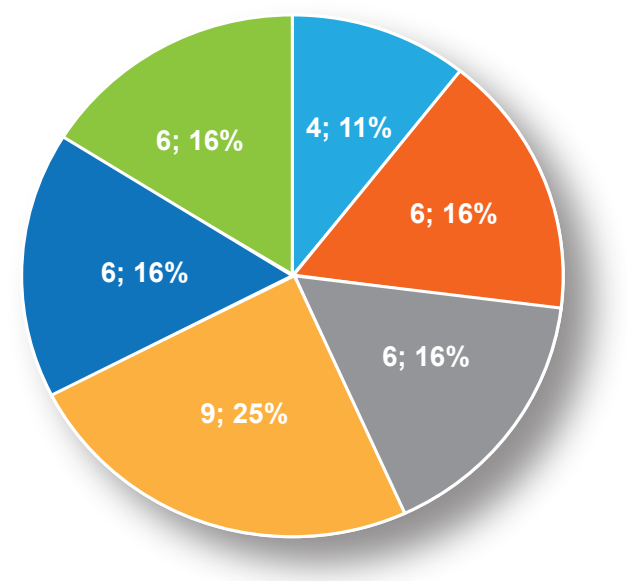
$0-18$
$19-25$
$26-35$
$36-45$
$46-55$
$56-71$

Figure 1 - Patient age group distribution

Percentage $(\%)$ and total number $(n)$ for each goup is presented

Table 1 - Patient characteristics

\begin{tabular}{|c|c|}
\hline Total number of patients & 37 \\
\hline Number of males (\%) & $29(78)$ \\
\hline Age (years), median (IQR) & $38 \pm 26$ \\
\hline Outdoor smoke exposure, n (\%) & 24 of $25(96)$ \\
\hline Duration of exposure (hours), median (IQR) & $6(96)$ \\
\hline \multicolumn{2}{|l|}{ Medical history, (n) } \\
\hline Asthma & 4 \\
\hline COPD & 1 \\
\hline \multicolumn{2}{|l|}{ Neurologic symptoms (n) } \\
\hline Headache & 23 \\
\hline Dizziness & 14 \\
\hline Nausea/vomiting & 10 \\
\hline Convulsion & 7 \\
\hline Confusion/lethargy/obtundation & 5 \\
\hline Loss of consciousness & 5 \\
\hline \multicolumn{2}{|l|}{ Cardiopulmonary symptoms (n) } \\
\hline Dyspnoea & 23 \\
\hline Cough & 7 \\
\hline Chest pain & 2 \\
\hline COHb (\%), median (IQR) & $3.7 \pm 2.7$ \\
\hline Time to HBOT chamber, median (IQR) & $4.8 \pm 9.5$ \\
\hline Chest X-ray (n) & 30, no acute changes \\
\hline \multicolumn{2}{|l|}{ Electrocardiographic findings (n) } \\
\hline Sinus rhythm & 15 \\
\hline Sinus tachycardia & 5 \\
\hline Nonspecific repolarizing findings & 1 \\
\hline \multicolumn{2}{|l|}{ Initial laboratory values, median (IQR) } \\
\hline $\mathrm{pH}$ & $7.42 \pm 0.14$ \\
\hline $\mathrm{pCO}_{2}(\mathrm{mmHg})$ & $35 \pm 14.1$ \\
\hline $\mathrm{pO}_{2}(\mathrm{mmHg})$ & $93 \pm 117.1$ \\
\hline $\mathrm{HCO}_{3}^{-}(\mathrm{mmol} / \mathrm{L})$ & $23 \pm 2.9$ \\
\hline Lactate $(\mathrm{mmol} / \mathrm{L})$ & $1.3 \pm 1.0$ \\
\hline CK (UI/L) & $363.5 \pm 389.5$ \\
\hline CK-MB (UI/L) & $21 \pm 9.5$ \\
\hline hsTroponin T & $0.009 \pm 0.013$ \\
\hline Creatinine (mg/dL) & $1.13 \pm 0.405$ \\
\hline Rhabdomyolysis (CK > 171 UI/L) n, (\%) & $20(54)$ \\
\hline AKI (creatinine > $1.20 \mathrm{mg} / \mathrm{dL}$ ) & $9(54)$ \\
\hline Rhabdomyolysis and AKI & $8(22)$ \\
\hline
\end{tabular}

IQR: interquartile range; COPD: chronic obstructive pulmonary disease; $\mathrm{COHb}$ : carboxihemoglobin; HBOT: hyperbaric oxygen therapy; CK: creatinine kinase; CK-MB: creatinine kinase muscle-brain fraction; AKI: acute kidney injury 
Table 2 - Median (IQR) comparison of admission $\mathrm{COHb}$ and time to HBOT chamber in patients with and without clinical symptoms of DNS at 30 days

\begin{tabular}{|c|c|c|c|}
\hline \multicolumn{4}{|c|}{ Clinical symptoms of DNS } \\
\hline & Yes & No & $p$ value \\
\hline $\mathrm{COHb}(\%)$ & $4.1(5.7)$ & $4.2(2.6)$ & 0.44 \\
\hline Time to HBOT (hours) & $9.1(12.7)$ & $5.9(10.7)$ & 0.58 \\
\hline
\end{tabular}

$\mathrm{COHb}$ : carboxihemoglobin; HBOT hyperbaric oxygen therapy; DNS: delayed neuropsychiatric syndrome; IQR: interquartile range

( $n=23$ ) followed by dizziness $(n=14)$. Moreover, five patients had syncope at the wildfire scene. Dyspnoea was the most frequent cardiopulmonary symptom, reported by 23 patients. Almost $50 \%$ of patients had symptoms related to two or more organs and systems ( $n=18)$. Electrocardiogram was normal in most patients although five patients exhibited sinus tachycardia.

Median $\mathrm{COHb}$ levels were not statistically different between smokers and non-smokers: 2.9 (IQR 4.5) and 3.7 (IQR 2.6) with $p=0.41$, respectively.

Laboratory findings were mostly normal, except for mild rhabdomyolysis (median creatinine kinase (CK) $363.5 \mathrm{UI} / \mathrm{L}$ ) and mild acute kidney injury [Acute Kidney Injury Network (AKIN) level 1]. Both findings were transient.

All patients arrived at the emergency department under oxygen therapy and received NBOT through admission until the HBOT session. The persistence of symptoms despite NBOT was the main indication for the use of HBOT in this context.

Median time to HBOT chamber was 4.8 hours (IQR 9.5). HBOT was performed at 15 metres (2.5 ATA) for 90 minutes, without major complications. Treatment had to be withheld temporarily in two patients due to transitory decreased mental status. Both patients soon resumed treatment without further complications. One patient had a second session after the first one was interrupted due to lipothymia.

Time to discharge was less than 24 hours in 34 patients $(92 \%)$ although one patient required short duration inpatient treatment for four days due to decompensated chronic obstructive pulmonary disease. Table 2 shows the differences in $\mathrm{COHb}$ concentration and time to HBOT between patients who went on to develop DNS at 30 days and the remaining patients.

\section{Delayed neuropsychiatric syndrome}

All patients were scheduled for a 30-day follow-up appointment. From the 37 patients, 12 were lost to followup, after missing the scheduled appointment. Of the 25 evaluated patients, five had clinical symptoms compatible with DNS, meaning an estimated incidence of $20 \%$ in this case series. Reassessment of patients and DNS diagnosis at 30 days was performed based on clinical interview and clinical examination for all patients. No structured questionnaire was used.

No new cases were registered at 12 months. One
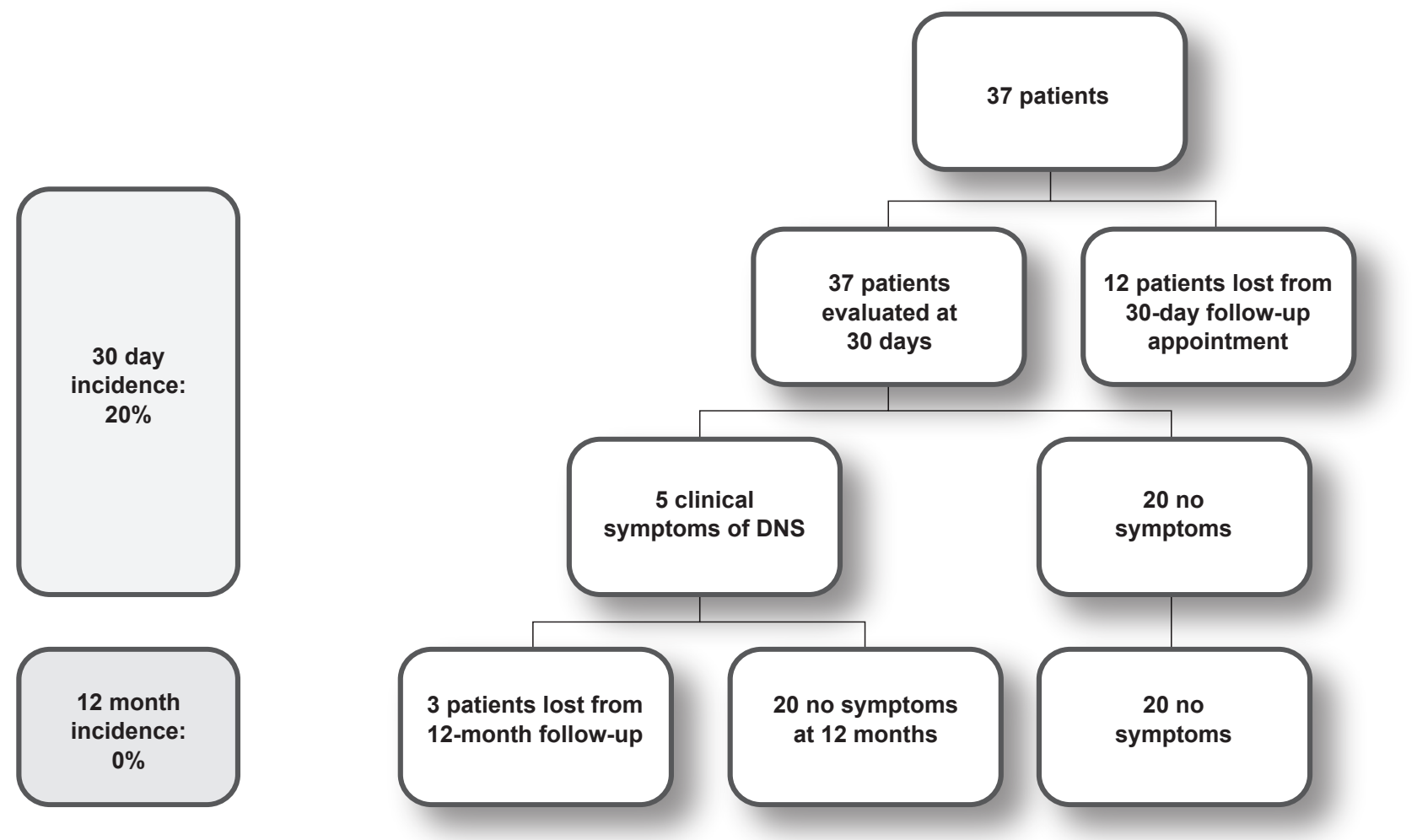

Figure 2 - Calculation of 30-day and 12-month incidence of DNS in this series 
patient mentioned de novo impairment of verbal fluency that started around six months after the intoxication. However, neurological consultation excluded DNS as cause for these findings. Fig. 2 allows for detailed data on follow-up losses and incidence calculation for this series.

\section{DISCUSSION}

Extreme environmental conditions in Funchal during the wildfires of August 2016 created a state of emergency and the need for the activation of a major response plan and proceedings. Due to its location, the island is equipped with a Hyperbaric Unit under 24-hour schedule with oncall specialist physicians, consisting of a 7-seat hyperbaric chamber. This allowed for a rapid intervention, with a quick start of HBOT in an unusually large number of patients in a short period.

This series also stands out by the number of patients who were intoxicated in an outdoor environment. According to reference Sá et al, the majority of $\mathrm{CO}$ intoxications in Portugal occur in indoors environments. ${ }^{4}$

Most patients had clinical symptoms compatible with target organ damage (neurologic or cardiovascular). The persistence of symptoms despite NBOT was the main reason for upfront HBOT upon arrival and quick initial approach to these patients. $\mathrm{COHb}$ levels of at least $3 \%-$ $4 \%$ in non-smokers and at least $10 \%$ in smokers are usually considered outside the expected physiological range. The $\mathrm{COHb}$ level in smokers is generally in the $3 \%-5 \%$ range. However, some of the patients in this series had lower levels. Despite this fact, most of these patients exhibited decreased mental status, convulsion or syncope. Due to these findings such patients underwent HBOT treatment. ${ }^{14,15}$ There were no statistically significant differences in $\mathrm{COHb}$ levels between smoker and non-smokers in this series.

As expected, most patients in this series presented with mild rhabdomyolysis. This is in line with $\mathrm{CO}$ toxicity of skeletal muscle through the binding of heme-containing proteins. ${ }^{5} \mathrm{~A}$ rise in troponin was also observed, as elsewhere reported and agrees with cardiac muscle injury through $\mathrm{CO}$ mediated pathways involving mitochondrial dysfunction and free radical generation. ${ }^{5,15}$

This case series includes other particular aspects such as inclusion of children and pregnant women. Both groups were assessed by paediatricians and obstetricians, respectively, prior to HBOT delivery. In all cases, treatment was well tolerated and none had the need to interrupt the session. Both fetus and mother showed no signs of distress before or after the treatment. Both groups should be treated like other patients with rapid initiation of NBOT and eventually HBOT. $^{13}$

Another strong reason for upfront institution of HBOT was to decrease the likelihood of late neurocognitive sequela, namely DNS.

\section{Delayed neuropsychiatric syndrome}

DNS may present through a spectrum of neuropsy- chiatric symptoms such as headache, difficulty concentrating, impairment of verbal fluency, lethargy, memory loss, dementia, psychosis, parkinsonism, chorea and peripheral neuropathy. ${ }^{5,8}$

The occurrence of late neurological syndrome at 30 days occurred in $20 \%$ of the reassessed patients in this series. Notably, there was no statistical difference in median $\mathrm{COHb}$ when comparing the patients with symptoms of DNS and patients with no apparent sequalae. Moreover, there was no statistical difference in time to HBOT delivery. However, it should be noted that the difference was roughly nine hours in the group that developed DNS and six hours in the comparison group. Clinically, this three hour difference may have played its role considering that HBOT should ideally be initiated within the first six hours, as effectiveness decreases after that. ${ }^{7}$ Nevertheless, the majority of patients received $\mathrm{HBOT}$ in a timely manner.

Overall, these results are in line with what is previously published elsewhere. Severity of initial symptoms and $\mathrm{COHb}$ level do not allow for prediction of development of DNS according to recent research. ${ }^{5}$ Predictors of cognitive impairment in the first six weeks post-exposure have been described and include age $\geq 36$ years, longer duration of CO exposure ( $\geq 24$ hours) and loss of consciousness at the scene. 5,18,19 $^{2}$

While most patients had low or moderate elevations of $\mathrm{COHb}$, and some had a paucity of symptoms, HBOT treatment was still delivered as means to decrease the likelihood of DNS development. Moreover, like elsewhere stated, the purpose of HBOT is the prevention of longterm and permanent neuropsychiatric sequalae, not improvement of short-term mortality rates, as these are around $3 \%$, and to the present, studies have failed to show survival improvement with HBOT.7,18 Furthermore, NBOT treatment alone was found be no better than no oxygen in the prevention of DNS. With this in mind, HBOT should be considered for all cases of serious acute CO poisoning, which include loss of consciousness, electrocardiographic abnormalities, neurological symptoms, metabolic acidosis, regardless of $\mathrm{COHb} .{ }^{13}$

Median time to HBOT ( $<6$ hours) shows a timely intervention from the prevention team that runs the Hyperbaric Unit, especially considering the underlying conditions where this case series unfolded. DNS may develop several months after the initial exposure, ${ }^{8,20}$ so a follow-up telephone contact was undertaken at 12 months for clinical screening of symptoms related to DNS. No patients referred symptoms suggestive of DNS that warranted clinical evaluation. Notably, a limitation on defining DNS in this study is that it was defined based on clinical interview only, and not through specific cognitive tests. Furthermore, a basal neurocognitive background was not available or reported. Unfortunately, guidelines on follow-up of neuropsychiatric symptoms of $\mathrm{CO}$ poisoning are lacking. ${ }^{20}$ 


\section{CONCLUSION}

Wildfires can cause clinically relevant $\mathrm{CO}$ poisoning, with typical signs and symptoms. This is a case of concern as Portugal experiences more and bigger wildfires each year.

We present a cohort of cases treated with HBOT that presented acutely to the emergency department in the time span of 72 hours, after $\mathrm{CO}$ poisoning from wildfires. This is an unheard number in Portugal at least. Availability of a hyperbaric chamber on location eased treatment with HBOT. While median $\mathrm{COHb}$ level was lower than other case series, the patients presented in an acute setting with persistent symptoms and with easy access to HBOT. Persistence of symptoms despite NBOT and an attempt to prevent DNS were the reasons for upfront $\mathrm{HBOT}$, regardless of $\mathrm{COHb}$ level. In this study, the central tendency for patients who did not develop DNS was a time to delivery of HBOT below six hours. This may add to evidence on the importance of early HBOT on the prevention of DNS. Nevertheless, our results should be interpreted cautiously due to the low number of cases as well as lack of a control group treated solely with NBOT. To the best of our knowledge, this is the first Portuguese case series that reports the use of HBOT exclusively in $\mathrm{CO}$ poisoning due to wildfire exposure. With this publication, the authors intend to raise awareness regarding the importance and need for referral of this type of patients who in exceptional situations may go unnoticed but whose formal indication and benefits for this type of treatment are well documented, especially as the country

\section{REFERENCES}

1. Hampson NB, Weaver L. Carbon monoxide poisoning: a new incidence for an old disease. Undersea Hyperb Med. 2007;34:163-8.

2. Hampson NB, Little CE. Hyperbaric treatment of patients with carbon monoxide poisoning in the United States. Undersea Hyperb Med. 2005;32:21-6.

3. Braubach M, Algoet A, Beaton M, Lauriou S, Héroux ME, Krzyzanowski M. Mortality associated 22 with exposure to carbon monoxide in WHO European member states. Indoor Air. 2013;23:115-25.

4. Sá MC, Rodrigues MP, Moura D. Internamentos por intoxicação com monóxido de carbono em Portugal. Acta Med Port 2011;24:727-34.

5. Rose JJ, Wang L, Xu Q, McTiernan CF, Shiva S, Tejero J, et al. Carbon monoxide poisoning: pathogenesis, management, and future directions of therapy. Am J Respir Crit Care Med. 2017;195:596-606.

6. Hampson NB, Dunn SL, UHMCS/CDC CO Poisoning Surveillance Group. Symptoms of carbon monoxide poisoning do not correlate with the initial carboxyhemoglobin level. Undersea Hyperb Med. 2012;39:657-65.

7. Hampson NB, Piantadosi CA, Thom SR, Weaver LK. Practice recommendations in the diagnosis, management, and prevention of carbon monoxide poisoning. Am J Respir Crit Care Med. 2012;186:1095101.

8. Thom SR, Taber RL, Mendiguren II, Clark JM, Hardy KR, Fisher AB. Delayed neuropsychologic sequelae after carbon monoxide poisoning: prevention by treatment with hyperbaric oxygen. Ann Emerg Med. 1995;25:474-80.

9. Ginsberg MD. Carbon monoxide intoxication: clinical features, neuropathology and mechanisms of injury. J Toxicol Clin Toxicol. 1985;23:281-8.

10. Hopkins R, Weaver, LK. Cognitive outcomes 6 years after acute carbon monoxide poisoning. Undersea Hyperb Med. 2008:258. has progressively experienced more and deadlier wildfires each year.

\section{ACKNOWLEDGEMENTS}

The authors would like to thank hyperbaric technicians Hélmut Calaboiça, Sílvio Mesquita and Vítor Silva for outstanding performance and data recording under critical circumstances. The authors further thank Carla D'Espiney Amaro and Francisco Gamito Guerreiro for proofreading the manuscript and providing valuable feedback.

\section{PROTECTION OF HUMAN AND ANIMAL SUBJECTS}

The authors declare that the research procedures were performed according to the regulations of the institution's ethics committee and the Code of Ethics of the World Medical Association (Declaration of Helsinki).

\section{CONFIDENTIALITY OF DATA}

The authors declare that they have followed the protocols of their work centre regarding the publication of data from patients.

\section{CONFLICT OF INTEREST}

The authors declare that they have no conflicts of interest.

\section{FINANCIAL SOURCES}

The authors declare that no funding was received.

11. Hsaio CL, Kuo HC, Huang CC. Delayed encephalopathy after carbon monoxide intoxication - long-term prognosis and correlation of clinical manifestations and neuroimages. Acta Neurol Taiwan. 2004;13:64-70.

12. Weaver LK, Valentine KJ, Hopkins R. Carbon monoxide poisoning: risk factors for cognitive sequelae and the role of hyperbaric oxygen. Am J Respir Crit Care Med. 2007;176:491-7.

13. Mathieu D, Marroni A, Kot J. Tenth European Consensus Conference on Hyperbaric Medicine: recommendations for accepted and non-accepted clinical indications and practice of hyperbaric oxygen treatment. Diving Hyperb Med. 2017;47:134.

14. Gozubuyuk AA, Dag H, Kacar A, Karakurt Y, Arica V. Epidemiology, pathophysiology, clinical evaluation, and treatment of carbon monoxide poisoning in child, infant, and fetus. North Clin Istamb. 2017;10;4:100-7.

15. Yurtseven S, Arslan A, Eryigit U, Gunaydin M, Tatli O, Ozsahin F, et al. Analysis of patients presenting to the emergency department with carbon monoxide intoxication. Turk J Emerg Med. 2016;15:159-62.

16. Macnow TE, Waltzman ML. Carbon monoxide poisoning in children: diagnosis and management in the emergency department. Pediatr Emerg Med Pract. 2016;13:1-24.

17. Friedman $P$, Guo XM, Stiller RJ, Laifer SA. Carbon monoxide exposure during pregnancy. Obstet Gynecol Surv. 2015;70:705-12.

18. Weaver LK. Clinical practice: carbon monoxide poisoning. N Engl J Med. 2009;360:1217-25.

19. Chiew AL, Buckley NA. Carbon monoxide poisoning in the 21 st century. Crit Care. 2014,18:221.

20. Quinn DK, McGahee SM, Politte LC, Duncan GN, Cusin C, Hopwood CJ, et al. Complications of carbon monoxide poisoning: a case discussion and review of the literature. Prim Care Companion J Clin Psychiatry. 2009;11:74-9. 